\section{Power Stations in Britain}

IN moving the second reading of the Electricity (Borrowing Powers) Bill in the House of Lords on March 3, the Minister of Power (Lord Mills) said that apart from the hydro-electric plant in the North of Scotland's programme, practically all the new generating plant, with a total capacity of $12 \cdot 25$ million kilowatts, which the Electricity Council intended to provide, would be coal-fired or nuclear, and it was estimated that nuclear power would absorb 47 per cent of the $£ 1,100$ million which the Central Electricity Generating Board proposed to spend on power-station construction. Of investment in power stations proposed over the next seven years, less than 4 per cent represented oil-fired plant, and within the past week, by agreement with the oil companies and the National Coal Board, conversion. of two power stations from coal to oil would be postponed for a year. At present there were five consortia of firms with design teams trained by the Atomic Energy Authority and capable of tendering for the construction of complete nuclear power stations. As the number of nuclear power stations that will be built in Britain before 1966 will not now exceed twelve to fourteen, the opportunities for a new consortium will be somewhat limited in future, although there were opportunities here and overseas for the manufacture of small reactors, including research reactors. If a British firm could obtain permission to make use of, say, American development work so that it could sell in export markets reactors of a different type from those developed here, he saw no reason why it should not do so.

Dealing with distribution, on which expenditure totalling $£ 700$ million was proposed for the seven years, Lord Mills said that at present nearly 75 per cent of farms had a supply of electricity, and the programme as a whole was expected to be completed on time. The proposed storage scheme at Festiniog and one projected at Loch Awe would eventually provide 700 megawatts at peak hours. Other research on storage was proceeding and he was satisfied that this research programme was adequate.

\section{University News :}

London

DR. A. R. Boothroyd, lecturer at the Imperial College of Science and Technology, has been appointed to the Unjversity readership in electronics tenable at that College; the title of reader in crystallography in the University has been conferred on Dr. C. H. Carlisle in respect of his post at Birkbeck College; Dr. R. F. Saxe, lecturer at Queen Mary College, has been appointed to the University readership in nuclear engineering tenable at that College.

Dr. B. J. Mason, Warren Research Fellow of the Royal Society at the Imperial College of Science and Technology, London, has been appointed visiting professor of meteorology by the University of California for the period June 1-December 31 .

Sheffield

The University of Sheffield has received, among others, three grants from the Department of Scientific and Industrial Research : one of more than $£ 15,000$, spread over five years, to the Department of Fuel Technology and Chemical Engineering, for the study of the formation and combustion of coal smoke; a grant of $£ 6,000$ over three years in aid of its work to the School of Social Studies, to investigate the transition to work of boys and girls from secondary modern schools in the Sheffield area; a grant of $£ 30,500$ over five years to the Department of Electrical Engineering, for the study of almost fully ionized gases by millimetre wave-probe techniques, involving building a small thermonuclear reactor, like Zeta, in the Department.

\section{Announcements}

The Gold Medal of the Royal Aeronautical Society, the highest honour the Society can confer, for work of an outstanding nature in aeronautics, has been awarded to M. Marcel Dassault, the well-known French aircraft designer, for "his outstanding contributions to the design and development of aircraft". One of the first aircraft designed by $M$. Dassault was the S.E.A.4 in 1918, and the last aeroplane to be designed by him was the Mirage $I V$, a high-speed twin-engine bomber. Between the Wars he designed many successful French aircraft, including fighters, reconnaissance types, bombers and transports.

Prof. S. J. ANGyal, head of the Department of Organic Chemistry, University of New South Wales, has been awarded the H. G. Smith Memorial Medal. The Medal is awarded every year by the Royal Australian Chemical Institute to the member who, in the opinion of the Council of the Institute, has contributed most to the development of some branch of chemical science.

The Operational Research Society has appointed Miss G. M. Heselton to be its secretary, and has moved into an office at 64 Cannon Street, E.C.4 (telephone, City 1800). The president is Prof. M. G. Kendall, of the London School of Economics, and the Operational Research Quarterly is published for the Society by Pergamon Press, Ltd.

Mr. Robert Douglas BaIRd has been appointed a director of Baird and Tatlock (London), Ltd., and of Hopkin and Williams, Ltd. Mr. Baird is a grandson of the founder of Baird and Tatlock (London), Ltd. He was educated at Winchester and Cambridge, where he read for the Mechanical Sciences Tripos. On leaving Cambridge, he joined the army in 1943; after demobilization in 1946 he returned to Cambridge to take the Certificate in Education, and since 1947 he has been teaching mathematics at Eton College, where he is also the careers master.

THE Physical Society is holding a Conference on Nuclear Physies in the University of Oxford during April 8-10. The Acoustics Group of the Society is holding a Symposium on New Techniques in the Analysis of Noise and Vibration jointly with the Institute of Physics in the Physics Department, University of Southampton, on April 7. Further information can be obtained from Miss E. Miles, Physical Society, I Lowther Gardens, London, S.W.7.

A National Education and Careers Exhibition, organized by the National Union of Teachers, is to be held at Olympia during May 26-June 5. The Education Section will display all aspects of modern education from nursery school to university and adult education. The Careers Section will offer information and advice on careers in virtually all the main fields of employment. Inquiries should be directed to the National Education and Careers Exhibition Office, Hamilton House, Mabledon Place, London, W.C.l. 